\title{
Peningkatan Kemampuan Membaca Pemahaman Melalui Penerapan Metode Survey, Question, Read, Recite, and Review (SQ3R) pada Siswa Kelas III di SDN. No. 054/XI Muara Air Tahun 2016/2017
}

\author{
Yusmaidar $^{1}$ \\ ${ }^{1}$ Guru SDN. No. 054/XI Muara Air, Kecamatan Kumun Debai, Kota Sungai Penuh, Provinsi Jambi \\ e-mail: y.yusmaidar22@gmail.com
}

\begin{abstract}
This study aims to improve the reading comprehension ability of grade III students at SDN. No. 054/XI Muara Air year 2016/2017 Through the Application of Survey, Question, Read, Recite, and Review (SQ3R) Methods. The research conducted is classroom action research. The study was conducted at SDN. No. 054/XI Muara Air, Kumun Debai District, Sungai Penuh City, Jambi Province. This study involved five third grade students. Classroom action research was conducted in two cycles, each cycle consisting of four activities, namely planning, implementation, observation, and reflection. The research data was collected through tests and processed using simple statistical tests. The results showed that the application of the SQ3R method can improve student learning activities. All students have been able to read reading material quickly and thoroughly, make questions based on the contents of the reading, write answers to questions that have been made, and dare to read the results in front of the class. In addition, students also have the courage to respond well to answering teacher questions and providing responses to the results of training from other students. The application of the SQ3R method can also improve student learning outcomes. The average value of students increased from 56.00 (pre-action) to 68.00 in Cycle I and 78.00 in Cycle II. In addition, student learning completeness also increased from $40.00 \%$ (pre-action) to $80.00 \%$ in Cycle I and 100.00\% in Cycle II. Thus, the application of the SQ3R method can improve the reading comprehension ability of third grade students at SDN. No. 054/XI Muara Air year 2016/2017.
\end{abstract}

Keywords: elementary school, Indonesian, learning activities, learning outcomes, SQ3R

\section{PENDAHULUAN}

Salah satu aspek bahasa yang perlu diperhatikan oleh guru adalah membaca. Membaca menjadi penting karena dengan membaca, siswa akan mendapatkan banyak informasi dari berbagai sumber yang dapat menambah wawasan mereka terhadap dunia dan perkembangannya.

Membaca terkadang dipandang sebagai kegiatan yang sederhana, namun sebenarnya itu adalah aktivitas yang kompleks. Tidak hanya berbicara tentang simbolsimbol yang berupa tulisan, tetapi juga untuk memahami tujuan dari teks. Dalam membaca, siswa diharapkan untuk mengamati, memahami, dan berpikir. Siswa perlu belajar untuk menganalisis bacaan/teks (memahaminya) atau dikenal dengan istilah membaca pemahaman. Menurut Somadayo (2011), membaca pemahaman merupakan suatu proses pemerolehan makna yang secara aktif melibatkan pengetahuan dan pengalaman yang telah dimiliki oleh pembaca serta dihubungkan dengan isi bacaan.

Beberapa hasil penelitian melaporkan bahwa guru menemukan kendalam dalam pembelajaran Bahasa Indonesia, khususnya di Sekolah Dasar. Lestari, Suyanto, dan Ngatman (2016) menemukan beberapa masalah dalam pebelajaran Bahasa Indonesia di kelas IV SDN Tanjungmeru tahun ajaran 2015/2016. Permasalahan tersebut adalah masih rendahnya keterampilan membaca intensif pada siswa yang terlihat dari rendahnya hasil belajar siswa dengan ketuntasan belajar sebesar 40,9\%. Permasalahan ini terjadi karena siswa kurang memahami isi bacaan, minat siswa untuk membaca kurang, penggunaan metode pembelajaran yang monoton dan tidak adanya penggunaan media belajar yang menarik serta penggunaan teknik membaca yang kurang sesuai.

Putri, Rukayah, dan Yulianti (2016) juga menemukan beberapa masalah dalam pebelajaran Bahasa Indonesia, yaitu keterampilan membaca pemahaman yang masih rendah, belum menggunakan model pembelajaran yang inovatif, fasilitas pendukung kegiatan membaca seperti perpustakaan juga belum berfungsi dengan baik sehingga menjadikan minat baca dan motivasi siswa rendah, siswa juga terlihat bosan. Kebanyakan guru hanya menyuruh siswa membaca tanpa bimbingan dan arahan guru, sedangkan guru tidak ikut membaca, sehingga mengakibatkan siswa kurang bersungguh-sungguh dan hanya sekilas saja membacanya. Masalah ini berdampak pada rendahnya hasil belajar siswa yang dibuktikan dengan ketuntasan belajar sebesar $33,33 \%$.

Choerunnisa, Triyono, \& Joharman (2016) menemukan juga beberapa masalah dalam pembelajaran Bahasa Indonesia di kelas V SD Negeri 01 Ngasem. Permasalahan tersebut adalah siswa kesulitan dalam memahami isi bacaan, siswa tidak dapat menjawab dengan cepat dan tepat pertanyaan yang diajukan, minat siswa untuk membaca rendah, dan motivasi siswa dalam mengikuti kegiatan pembelajaran kurang yang berakibat pada rendahnya hasil belajar yang diperoleh siswa. Selain itu, Ambarsari, Suhartono, \& Suyanto (2015) mengemukakan bahwa kemampuan membaca pemahaman di SD Negeri Trirejo masih rendah yang terlihat dari ketuntasan belajar siswa hanya mencapai $45 \%$ dengan nilai rata-rata sebesar 68,95 . Hal ini terjadi karena guru menggunakan metode yang monoton dan konvensional yaitu mengguna-kan metode ceramah dan penugasan yang mengakibatkan siswa merasa jenuh dan kurang tertarik pada pembelajaran Bahasa Indonesia.

Permasalahan ini juga terjadi di kelas III SDN. No. 054/XI Muara Air. Hasil uji penjajakan menunjukkan bahwa Hasil belajar siswa tergolong dalam kategori rendah. Hasil tes penjajakan menunjukkan bahwa nilai yang diperoleh siswa berada pada rentang 45,00-70,00 dengan nilai rata-rata sebesar 56,00 dan ketuntasan belajar sebesar $40,00 \%$. Selain itu, hasil pengamatan 
juga menunjukkan bahwa kemampuan siswa dalam memahami isi bacaan masih rendah yang terlihat ketika siswa mengalami kesulitan dalam menjawab pertanyaan guru tentang isi dari bacaan yang dibaca. Selain itu, guru menggunakan metode pembelajaran yang konvensional dan monoton sehingga siswa kurang antusias dalam mengikuti kegiatan pembelajaran.

Salah satu cara yang dapat digunakan untuk mengatasi rendahnya kemampuan membaca pemahaman pada siswa adalah dengan menggunakan metode Survey, Question, Read, Recite, and Review atau yang dikenal dengan istilah SQ3R (Siskalia, Kartono, \& Halidjah, 2014; Ambarsari, Suhartono, \& Suyanto, 2015; Lestari, Suyanto, dan Ngatman, 2016; Choerunnisa, Triyono, dan Joharman, 2016; Putri, Rukayah, \& Yulianti, 2016). Berdasarkan pemaparan tersebut, guru tertarik untuk melakukan penelitian yang berjudul "Peningkatan Kemampuan Membaca Pemahaman Melalui Penerapan Metode Survey, Question, Read, Recite, and Review (SQ3R) pada Siswa Kelas III di SDN. No. 054/ XI Muara Air Tahun 2016/2017".

Penelitian ini bertujuan untuk meningkatkan kemampuan membaca pemahaman pada siswa kelas III di SDN. No. 054/ XI Muara Air Tahun 2016/ 2017 melalui penerapan metode Survey, Question, Read, Recite, and Review (SQ3R).

\section{METODE PENELITIAN}

Penelitian ini merupakan penelitian tindakan kelas (PTK). Penelitian dilakukan di SDN. No. 054/XI Muara Air, Kecamatan Kumun Debai, Kota Sungai Penuh, Provinsi Jambi. Kegiatan penelitian terdiri atas penyusunan proposal penelitian, pengumpulan data, pengolahan data, analisis data, dan penyusunan laporan. Penelitian dilakukan sejak bulan Maret sampai dengan bulan Juni tahun 2017

Subjek dalam penelitian ini adalah siswa kelas III semester genap tahun pelajaran 2016/2017 di SDN. No. 054/XI Muara Air, Kecamatan Kumun Debai, Kota Sungai Penuh, Provinsi Jambi. Jumlah subjek yang terlibat dalam penelitian ini adalah 5 orang siswa. Objek dalam penelitian ini adalah peningkatan kemampuan membaca pemahaman yang dilihat dari hasil belajar siswa kelas III di SDN. No. 054/XI Muara Air pada mata pelajaran Bahasa Indonesia.

Data hasil belajar siswa dikumpulkan dengan cara pengamatan/observasi dan tes. Observasi merupakan cara untuk menghimpun data atau bahan-bahan keterangan yang dilakukan dengan mengadakan pengamatan dan pencatatan secara sistematis terhadap fenomena-fenomena yang sedang dijadikan sasaran pengamatan. Dalam penelitian ini, observasi dilakukan untuk mengamati tingkah laku siswa selama proses pembelajaran berlangsung. Selanjutnya, evaluasi hasil belajar jenis tes merupakan cara untuk melakukan proses penilaian dalam bentuk tugas atau serangkaian tugas yang harus dikerjakan siswa atau sekelompok siswa sehingga menghasilkan suatu nilai yang menggambarkan prestasi siswa.

Data yang telah dikumpulkan diolah dan dianalisis dengan menggunakan uji statistic sederhana. Uji statistik sederhana digunakan untuk menghitung nilai rata-rata dan ketuntasan belajar. Penghitungan nilai rata-rata hasil belajar siswa dengan menggunakan rumus:

Nilai rata-rata $=\frac{\sum \text { Nilai Siswa }}{\text { Jumlah siswa }} \times 100$

Penghitungan persentase ketuntasan belajar siswa dengan menggunakan rumus:

Persentase ketuntasan belajar siswa (\%) = $\frac{\sum \text { Siswa yang tuntas }}{\text { Jumlah siswa }} \times 100$

Selanjutnya, nilai rata-rata dan persentase ketuntasan belajar siswa yang diperoleh dianalisis dengan cara membandingkan nilai rata-rata yang diperoleh siswa sebelum dan sesudah tindakan.

Indikator keberhasilan dari penelitian tindakan kelas ini adalah peningkatan kemampuan membaca pemahaman siswa kelas III SDN. No. 054/XI Muara Air tahun 2016/2017 yang dilihat dari hasil belajar siswa. Selanjutnya, hasil belajar yang diperoleh setiap siswa dibandingkan dengan Kriteria Ketuntasan Minimum (KKM) kompetensi dasar mata pelajaran Bahasa Indonesia yang telah ditentukan oleh sekolah diawal tahun pelajaran 2016/2017 yaitu sebesar 60,0.

\section{HASIL DAN PEMBAHASAN Pratindakan}

Sebelum memberikan tindakan, guru mengadakan tes penjajakan terlebih dahulu pada siswa. Hasil tes penjajakan disajikan pada Tabel 1.

Tabel 1 Hasil tes penjajakan

\begin{tabular}{cllll}
\hline No & Nama Siswa & KKM & Nilai & Keterangan \\
\hline 1 & Dirga & 60,0 & 60,0 & Tuntas \\
2 & Kaka Andriano & 60,0 & 45,0 & Tidak Tuntas \\
3 & Keken & 60,0 & 50,0 & Tidak Tuntas \\
4 & Pathar & 60,0 & 55,0 & Tidak Tuntas \\
5 & Zahira & 60,0 & 70,0 & Tuntas \\
Nilai Tertinggi & & 70,0 & \\
Nilai Terendah & & 45,0 & \\
Nilai Rata-Rata & & 56,0 & \\
Ketuntasan Belajar (\%) & & 40,0 & \\
\hline
\end{tabular}

Data yang disajikan pada Tabel 2 menunjukkan bahwa nilai terendah siswa adalah 45,00 dan nilai tertinggi adalah 70,00. Nilai rata-rata yang diperoleh 6 orang siswa adalah 56,00. Apabila dibandingkan antara nilai siswa dengan KKM kompetensi dasar maka diperoleh hasil bahwa sebanyak 2 orang siswa telah memiliki nilai sama dan lebih dari pada KKM kompetensi dasar. Artinya, sebanyak 2 orang siswa tuntas. Sisanya, sebanyak 3 orang siswa belum tuntas. Persentase ketuntasan belajar sebesar 40,00\%. Hasil ini menunjukkan bahwa nilai rata-rata dan persentase ketuntasan belajar siswa termasuk dalam kategori rendah. Guru perlu mencari solusi untuk masalah ini dengan cara memperbaiki metode yang digunakan dalam kegiatan pembelajaran. Dalam penelitian ini, metode yang digunakan untuk meningkatkan kemampuan membaca pemahaman siswa adalah metode SQ3R (survey, question, read, recite, and review). 


\section{Hasil Penelitian Siklus I}

Siklus I dilakukan pada 3-10 April 2017. Kegiatan pada siklus I terdiri atas perencanaan, pelaksanaan, pengamatan, dan refleksi.

Perencanaan. Kegiatan perencanaan terdiri atas: merumuskan tujuan pembelajaran; memilih dan mengorganisasi materi ajar; memilih sumber belajar/media pembelajaran; menyusun skenario/kegiatan pembelajaran; dan menyiapkan alat evaluasi hasil belajar

Pelaksanaan. Kegiatan pelaksanaan tindakan terdiri atas: Guru mengucapkan salam dan menanyakan keadaan siswa; Guru memeriksa kehadiran siswa; Guru menyampaikan tujuan pembelajaran; Guru menyampaikan skenario pembelajaran yang akan dilaksanakan; Guru melakukan apersepsi; Guru meminta siswa membaca cepat bahan bacaan; Guru memberikan tugas kepada mahasiswa untuk membuat pertanyaan berdasarkan bacaan; Guru meminta siswa untuk membaca kembali bacaan dengan teliti; Guru meminta siswa untuk mencatat jawaban dari pertanyaan yang telah dibuat; Guru meminta siswa untuk membaca hasil latihannya di depan kelas; Guru memberikan kesempatan kepada siswa lain untuk memberikan tanggapan; Guru memberikan penguatan mengenai materi yang telah dibahas; Guru bersama siswa membuat kesimpulan kegiatan; Guru memberikan gambaran kegiatan berikutnya; Guru melakukan evaluasi hasil belajar; Guru menyampaikan pesan moral.

Pengamatan. Hasil pengamatan me-nunjukan bahwa sebagian besar siswa telah mendengarkan penjelasan guru dengan antusias. Hasil pengamatan juga menunjukkan bahwa siswa telah mampu membaca bahan bacaan dengan cepat dan teliti, membuat pertanyaan berdasarkan isi bacaan, menuliskan jawaban atas pertanyaan yang telah dibuat, dan berani membacakan hasil di depan kelas. Selain itu, siswa juga telah berani memberikan tanggapan baik tanggapan dalam menjawab pertanyaan guru maupun memberikan tanggapan mengenai hasil latihan dari siswa lain. Secara ringkas, hasil pengamatan disajikan pada Tabel 2.

Tabel 2. Hasil pengamatan aktivitas belajar siswa pada Siklus I

\begin{tabular}{clcc}
\hline No & \multicolumn{1}{c}{ Indikator } & Jumlah & Persen \\
\hline 1 & $\begin{array}{l}\text { Siswa mendengarkan penjelasan guru } \\
\text { dengan antusias }\end{array}$ & 6 & 100,0 \\
2 & $\begin{array}{l}\text { Siswa membaca bahan bacaan dengan } \\
\text { cepat }\end{array}$ & 5 & 80,0 \\
3 & $\begin{array}{l}\text { Siswa membuat pertanyaan } \\
\text { berdasarkan isi bacaan }\end{array}$ & 5 & 80,0 \\
4 & $\begin{array}{l}\text { Siswa membaca bahan bacaan dengan } \\
\text { teliti }\end{array}$ & 5 & 80,0 \\
5 & $\begin{array}{l}\text { Siswa menuliskan jawaban atas } \\
\text { pertanyaan yang telah dibuat }\end{array}$ & 5 & 80,0 \\
6 & $\begin{array}{l}\text { Siswa berani membacakan hasil di } \\
\text { depan kelas }\end{array}$ & 5 & 80,0 \\
7 & Siswa berani memberikan tanggapan & 5 & 80,0 \\
\hline
\end{tabular}

Hasil evaluasi dengan tes disajikan pada Tabel 3. Data yang disajikan pada Tabel 3 menunjukkan bahwa nilai terendah siswa adalah 55,0 dan nilai tertinggi adalah 80,0 . Nilai rata-rata yang diperoleh 5 orang siswa adalah 68,00 . Apabila dibandingkan antara nilai siswa dengan KKM kompetensi dasar maka diperoleh hasil bahwa sebanyak 4 orang siswa telah memiliki nilai yang lebih besar dari pada KKM kompetensi dasar. Artinya, sebanyak 4 orang siswa tuntas. Sisanya, sebanyak 1 orang siswa belum tuntas. Persentase ketuntasan belajar sebesar $80,0 \%$. Hasil ini meningkat sebesar 11,0 point dibandingkan pada saat tes penjajakan yang hanya sebesar 56,0 . Ketuntasan belajar juga meningkat sebesar 40,0\% dibandingkan dengan kondisi tes penjajakan yaitu sebesar $40,0 \%$. Dengan demikian, penerapan metode SQ3R telah menunjukkan bahwa terjadi peningkatan hasil belajar siswa setelah diberikan tindakan, baik peningkatan pada nilai rata-rata maupun dalam hal peningkatan ketuntasan belajar secara klasikal.

\section{Tabel 3. Hasil penelitian pada Siklus I}

\begin{tabular}{clcll} 
No & Nama Siswa & KKM & Nilai & Keterangan \\
\hline 1 & Dirga & 60,0 & 75,0 & Tuntas \\
2 & Kaka Andriano & 60,0 & 55,0 & Tidak Tuntas \\
3 & Keken & 60,0 & 60,0 & Tuntas \\
4 & Pathar & 60,0 & 70,0 & Tuntas \\
5 & Zahira & 60,0 & 80,0 & Tuntas \\
Nilai Tertinggi & & 80,0 & \\
Nilai Terendah & & 55,0 & \\
Nilai Rata-Rata & & 68,0 & \\
Ketuntasan Belajar (\%) & & 80,0 & \\
\hline
\end{tabular}

Refleksi. Peningkatan hasil belajar sudah mulai terlihat baik dari nilai rata-rata maupun dari ketuntasan belajar. Dengan demikian, pemberian tindakan perlu dilanjutkan. Hasil pengamatan menunjukan bahwa sebagian besar siswa telah mendengarkan penjelasan guru dengan antusias, membaca bahan bacaan dengan cepat dan teliti, membuat pertanyaan berdasarkan isi bacaan, menuliskan jawaban atas pertanyaan yang telah dibuat, dan berani membacakan hasil di depan kelas, serta berani memberikan tanggapan baik tanggapan. Berdasarkan hasil siklus I, guru perlu melakukan perbaikan dalam pelaksanaan pembelajaran pada Siklus II.

\section{Hasil Penelitian Siklus II}

Siklus II dilakukan pada 17-26 April 2017. Siklus II terdiri atas empat kegiatan yaitu perencanaan, pelaksanaan, pengamatan, dan refleksi.

Kegiatan perencanaan terdiri atas: merumuskan tujuan pembelajaran; memilih dan mengorganisasi materi ajar; memilih sumber belajar/media pembelajaran; menyusun skenario/kegiatan pembelajaran; dan menyiapkan alat evaluasi hasil belajar

Kegiatan pelaksanaan tindakan terdiri atas: Guru mengucapkan salam dan menanyakan keadaan siswa; Guru memeriksa kehadiran siswa; Guru menyampaikan tujuan pem-belajaran; Guru menyampaikan skenario pem-belajaran yang akan dilaksanakan; Guru melakukan apersepsi; Guru meminta siswa membaca cepat bahan bacaan; Guru memberikan tugas kepada mahasiswa untuk membuat pertanyaan berdasarkan bacaan; Guru meminta siswa untuk membaca kembali bacaan dengan teliti; Guru meminta siswa untuk mencatat jawaban dari pertanyaan yang telah dibuat; Guru meminta siswa untuk membaca hasil latihannya di 
depan kelas; Guru memberikan kesempatan kepada siswa lain untuk memberikan tanggapan; Guru memberikan penguatan mengenai materi yang telah dibahas; Guru bersama siswa membuat kesimpulan kegiatan; Guru memberikan gambaran kegiatan berikutnya; Guru melakukan evaluasi hasil belajar; Guru menyampaikan pesan moral.

Pengamatan. Secara ringkas, hasil pengamatan disajikan pada Tabel 4.

Tabel 4. Hasil pengamatan aktivitas belajar siswa pada Siklus II

\begin{tabular}{clcc}
\hline No & \multicolumn{1}{c}{ Indikator } & Jumlah & Persen \\
\hline 1 & $\begin{array}{l}\text { Siswa mendengarkan penjelasan guru } \\
\text { dengan antusias }\end{array}$ & 6 & 100,0 \\
2 & $\begin{array}{l}\text { Siswa membaca bahan bacaan dengan } \\
\text { cepat }\end{array}$ & 6 & 100,0 \\
3 & $\begin{array}{l}\text { Siswa membuat pertanyaan } \\
\text { berdasarkan isi bacaan }\end{array}$ & 6 & 100,0 \\
4 & $\begin{array}{l}\text { Siswa membaca bahan bacaan dengan } \\
\text { teliti }\end{array}$ & 6 & 100,0 \\
5 & $\begin{array}{l}\text { Siswa menuliskan jawaban atas } \\
\text { pertanyaan yang telah dibuat }\end{array}$ & 6 & 100,0 \\
6 & $\begin{array}{l}\text { Siswa berani membacakan hasil di } \\
\text { depan kelas }\end{array}$ & 6 & 100,0 \\
7 & Siswa berani memberikan tanggapan & 6 & 100,0 \\
\hline
\end{tabular}

Pengamatan. Hasil pengamatan menunjuk-kan bahwa seluruh siswa telah mendengarkan penjelasan guru dengan antusias. Hasil pengamatan juga menunjukkan bahwa siswa telah mampu membaca bahan bacaan dengan cepat dan teliti, membuat pertanyaan berdasar-kan isi bacaan, menuliskan jawaban atas per-tanyaan yang telah dibuat, dan berani mem-bacakan hasil di depan kelas. Selain itu, siswa juga telah berani memberikan tanggapan baik tanggapan dalam menjawab pertanyaan guru maupun memberikan tanggapan mengenai hasil latihan dari siswa lain.

Hasil evaluasi dengan tes disajikan pada Tabel 5. Tabel 5 menginformasikan bahwa nilai terendah siswa adalah 65,0 dan nilai tertinggi adalah 90,0. Nilai rata-rata yang diperoleh 6 orang siswa adalah 78,0. Seluruh siswa telah memiliki nilai yang lebih besar dari pada KKM kompetensi dasar dengan persentase ketuntasan sebesar $100,0 \%$. Nilai rata-rata yang diperoleh siswa meningkat sebesar 10,0 point dibandingkan nilai ratarata yang diperoleh siswa pada Siklus I yaitu sebesar 68,0 . Selain itu, persentase ketuntasan belajar siswa juga meningkat 20,0\% apabila dibandingkan dengan siklus I. Nilai rata-rata dan persentase ketuntas-an belajar siswa meningkat dibandingkan dengan siklus I.

Tabel 5. Hasil penelitian pada Siklus II

\begin{tabular}{clccl}
\hline No & Nama Siswa & KKM & Nilai & Keterangan \\
\hline 1 & Dirga & 60,0 & 85,0 & Tuntas \\
2 & Kaka Andriano & 60,0 & 65,0 & Tuntas \\
3 & Keken & 60,0 & 70,0 & Tuntas \\
4 & Pathar & 60,0 & 80,0 & Tuntas \\
5 & Zahira & 60,0 & 90,0 & Tuntas \\
Nilai Tertinggi & & 90,0 & \\
Nilai Terendah & & 65,0 & \\
Nilai Rata-Rata & & 78,0 & \\
Ketuntasan Belajar (\%) & & 100,0 & \\
\hline
\end{tabular}

Refleksi. Aktivitas dan hasil belajar siswa semakin membaik sehingga pelaksanaan penelitian tindakan kelas dihentikan. Guru sebaiknya tetap melanjutkkan penggunaan metode ini untuk meningkatkan aktivitas dan hasil belajar siswa. Guru memberikan pengayaan pada siswa yang belum tuntas. Guru sebaiknya meningkatkan pengetahuan tentang metode/model/strategi pembelajaran dan juga tentang media pembelajaran. Pengetahuan ini akan membantu guru dalam menerapkan metode/model/strategi pembelajaran yang beragam dan inovatif. Guru juga melakukan evaluasi pembelajaran baik proses maupun evaluasi hasil secara berkala untuk menjaga kualitas pembelajaran. Selain itu, guru juga perlu memberikan motivasi pada siswa untuk meningkatkan kepercayaan dirinya.

\section{Analisis Hasil}

Pengertian dan konsep dasar tentang belajar memiliki tafsir dan terjemahan yang berbeda-beda bergantung pada siapa dan dudut pandang mana menafsirkannya. Sugiyono dan Hariyanto (2011) mengartikan belajar sebagai sebuah aktivitas untuk memperoleh pengetahuan, meningkatkan keterampilan, memperbaiki perilaku, sikap, dan mengukuhkan kepribadian. Belajar juga didefinisikan sebagai sebuah proses yang dilakukan oleh individu untuk memperoleh pengetahuan dan pengalaman baru yang diwujudkan dalam bentuk perubahan tingkah laku yang relatif permanen dan menetap disebabkan adanya interaksi individu dengan lingkungan belajarnya (Irham dan Wiyani, 2013). Dengan demikian, belajar merupakan sebuah proses untuk meningkatkan pengetahuan, keterampilan, dan juga sikap.

Proses belajar dan mengajar memiliki tujuantujuan tertentu yang ingin dan harus dicapai. Baik atau buruknya suatu proses pembelajaran dapat diketahui dengan cara melakukan evaluasi hasil belajar pada siswa yang menjadi subjek utama dalam kegiatan pembelajaran. Hasil belajar adalah tingkat penguasaan yang dicapai oleh pelajar dalam mengikuti proses belajar mengajar sesuai dengan tujuan pendidikan yang ditetapkan (Hamalik, 2003).

Dalam penelitian ini, hasil belajar siswa dinilai dari nilai rata-rata kelas dan persentase ketuntasan belajar siswa. Hasil penelitian pada Gambar 1 menunjukkan bahwa nilai rata-rata siswa meningkat dari 56,0 (pratindakan) menjadi 68,0 (Siklus I) dan kembali meningkat menjadi 78,0 (Siklus II). Selain itu, ketuntasan belajar siswa juga meningkat dari 60,0\% (Pratindakan) menjadi 80,0\% (Siklus I) dan kembali meningkat menjadi $100,0 \%$ (Siklus II). Dengan demikian, penerapan metode SQ3R dapat meningkatkan kemampuan membaca pemahaman pada siswa kelas III di SDN. No. 054/XI Muara Air tahun 2016/2017. Hasil penelitian mendukung temuan sebelumnya bahwa penerapan metode SQ3R dapat meningkatkan kemampuan membaca pemahaman pada siswa di sekolah dasar (Siskalia, Kartono, \& Halidjah, 2014; Ambarsari, Suhartono, \& Suyanto, 2015; Lestari, Suyanto, dan Ngatman, 2016; Putri, Rukayah, \& Yulianti, 2016; Choerunnisa, Triyono, dan Joharman, 2016; Putri, Rukayah, \& Yulianti, 2016). 


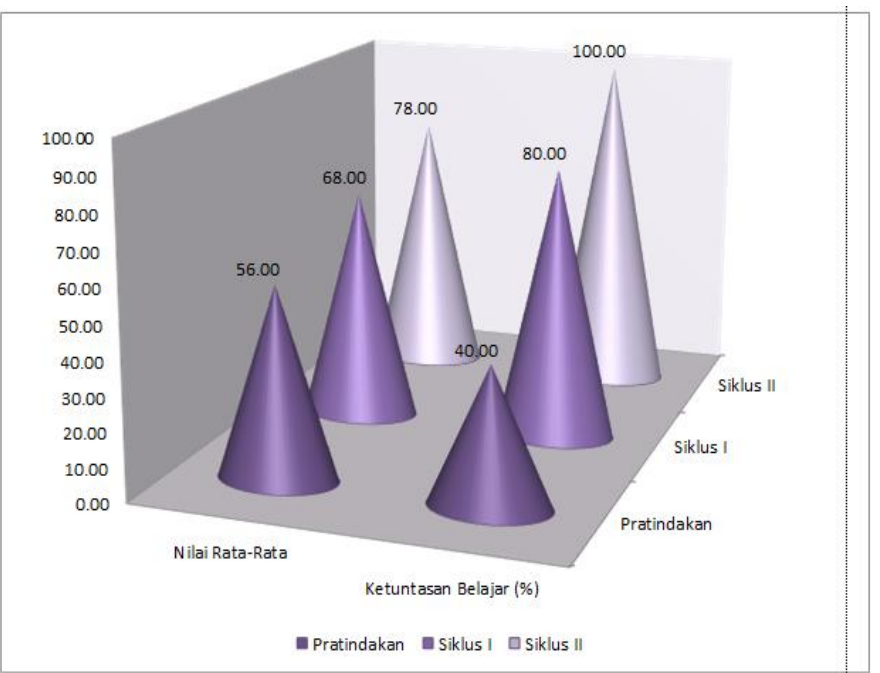

Gambar 1 Rekapitulasi hasil belajar siswa pada saat pratindakan, siklus I, dan siklus II

\section{SIMPULAN}

Hasil penelitian menunjukkan bahwa penerapan metode SQ3R dapat meningkatkan aktivitas belajar siswa. Seluruh siswa telah mampu membaca bahan bacaan dengan cepat dan teliti, membuat pertanyaan berdasarkan isi bacaan, menuliskan jawaban atas pertanyaan yang telah dibuat, dan berani membacakan hasil di depan kelas. Selain itu, siswa juga telah berani memberikan tanggapan baik tanggapan dalam menjawab pertanyaan guru maupun memberikan tanggapan mengenai hasil latihan dari siswa lain. Penerapan metode SQ3R juga dapat meningkatkan hasil belajar siswa. Nilai rata-rata siswa meningkat dari 56,00 (pratindakan) menjadi 68,00 pada Siklus I dan 78,00 pada Siklus II. Selain itu, ketuntasan belajar siswa juga meningkat dari 40,00\% (Pratindakan) menjadi $80,00 \%$ pada Siklus I dan $100,00 \%$ pada Siklus II. Dengan demikian, penerapan metode SQ3R dapat meningkatkan kemampuan pemahaman siswa kelas III di SDN. No. 054/XI Muara Air tahun 2016/2017.

\section{DAFTAR PUSTAKA}

Ambarsari, Y., Suhartono, \& Suyanto, I. (2015). Penerapan Metode SQ3R dalam Peningkatan Kemampuan Membaca Pemahaman Siswa Kelas V SD Negeri Trirejo. Kalam Cendekia PGSD Kebumen, 3(4).

Choerunnisa, F, Triyono, \& Joharman. (2016). Penggunaan Metode Survey, Question, Read, Recite, Review (SQ3R) untuk Meningkatkan Keterampilan Membaca Pemahaman bagi Siswa Kelas V SD N 3 Tamanwinangun Tahun Ajaran 2015/2016. Kalam Cendekia PGSD Kebumen, 4(1.1), halaman 89-93.

Hamalik, O. (2003). Proses Belajar Mengajar. Jakarta: Bumi Aksara.

Irham, M., \& Wiyani, N. A. (2013). Psikologi Pendidikan: Teori dan Aplikasi dalam Proses Pembelajaran. Yogyakarta: Ar Ruzz Media.

Lestari, Suyanto, dan Ngatman. (2016). Penerapan Metode Survey-Question-Read-Recite-Review (SQ3R) Dengan Media Cetak Untuk Meningkatkan Keterampilan Membaca Intensif
Pada Siswa Kelas IV SDN Tanjungmeru Tahun Ajaran 2015/2016. Kalam Cendekia PGSD Kebumen, 4(1), halaman 105-109.

Putri, A.D.S., Rukayah, \& Yulianti. (2016). Penggunaan Metode Pembelajaran SQ3R (Survey, Question, Read, Recite, Review) untuk Meningkatkan Keterampilan Membaca Pemahaman dalam Mata Pelajaran Bahasa Indonesia. Kalam Cendekia PGSD Kebumen, 4(2), halaman 93-98.

Sadhono, K., \& Slamet, S.Y. (2012). Meningkatkan Keterampilan berbahasa Indonesia (teori dan Aplikasi). Bandung: Karya Putra Darwati

Siskalia, Kartono, \& Halidjah, S. (2014). Peningkatan Kemampuan Membaca Pemahaman Menggunakan Metode Survey Question Read Recite Review di Sekolah Dasar [Skripsi]. Pontianak: PGSD, FKIP, Universitas Tanjungpura.

Somadayo, S. (2011). Strategi dan Teknik Pembelajaran Membaca. Yogyakarta: Graha Ilmu.

Sugiyono \& Hariyanto. (2011). Belajar dan Pembelajaran: Teori dan Konsep Dasar. Bandung: Remaja Rosdakarya. 